\title{
FISCAL INSTRUMENTS OF TAXATION IMPROVEMENT AS A FACTOR OF SUSTAINABLE DEVELOPMENT OF ENTERPRISES OF THE FUEL AND ENERGY SECTOR
}

\author{
Allaeva G.Zh \\ Tashkent state technical university, University street №2, Tashkent.
}

\begin{abstract}
The article discusses the main directions of improving tax administration at the enterprises of the fuel and energy complex. A fiscal tool is proposed to improve tax administration in the form of a mechanism to reduce the tax burden of enterprises in the energy sector. The influence of resource taxes on the effective economic development of extractive energy enterprises is studied.
\end{abstract}

One of the most important aspects of ensuring the innovative development of fuel and energy companies is the availability of sufficient financial resources for the creation and implementation of innovative projects. This aspect is fully in line with the continuing efforts to reduce the tax burden and simplify the tax system, improve tax administration and expand incentives.

As a way of solving this problem, the author has proposed a fiscal instrument for improving tax administration in the form of a mechanism for reducing the tax burden on energy sector companies. Applying this mechanism in practice would free up additional resources to stimulate innovation activities in these enterprises. This is especially important for oil and gas producing enterprises in Uzbekistan.

Resources taxes, including subsoil use taxes, have the greatest impact on the company's business. As it was mentioned earlier, these taxes account for almost $40 \%$ of all payments or about $60 \%$ of payments without VAT and excise duties.

Resource taxes are included in the cost of sales, i.e., they reduce the overall financial result before taxes are paid. On average, in the last five years, taxes accounted for in cost of sales reduced profit by almost $101 \%$ to the total financial result before taxes, including more than
$65 \%$ subsoil use tax. At the same time, while in 2016 resource taxes accounted for more than $72 \%$ of the profit received, including more than $50 \%$ of the subsoil use tax, in 2019 they already accounted for more than $100 \%$ of the profit before taxes, and the subsoil use tax for $76 \%$.

For the quantitative assessment of fiscal regimes in the world practice use such an indicator as the share of state seizures. It is estimated as the ratio of taxes to profit (income) before they are paid.

The use of this parameter is not accidental: the tax system should be correlated with economic efficiency. If an effective field becomes inefficient before taxes, the tax system becomes inadequate because it makes investments in oil and gas production ineffective. The level at which an enterprise becomes unattractive for investments is $100 \%$ and higher. By 2019, all taxes in the Company's enterprises exceeded the limit almost 3.5 times, and without VAT and excise duties - 2.4 times, with a clear upward trend. On the basis of reporting data on JSC "Uzbekneftegazdobycha", dynamics of change of share of withdrawal of funds by the state in the form of taxes (as a percentage of profit before taxes on extracting enterprises of JSC "Uzneftegazdobycha") was analyzed (Fig. 1.).

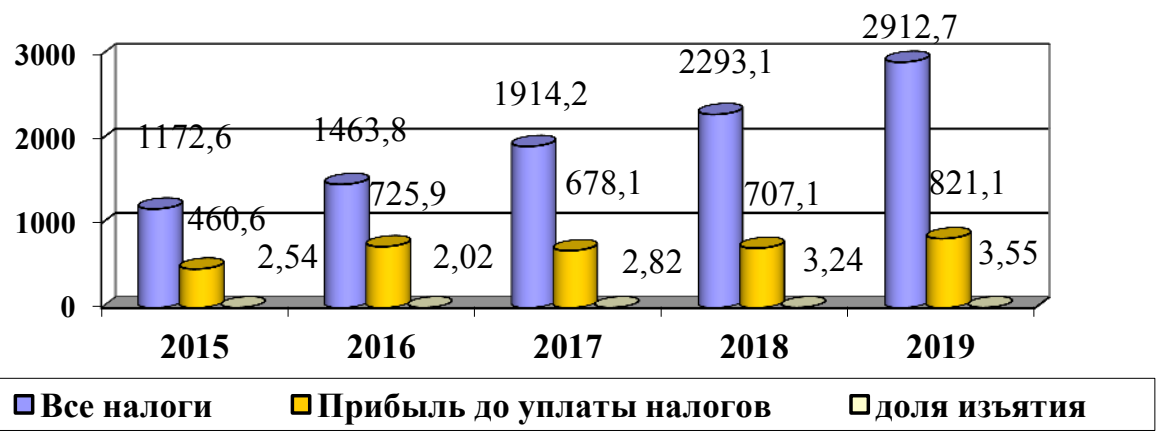

Fig. 1. Dynamics of share of withdrawal of funds by state in form of taxes (in percentage of profit before taxes on extracting enterprises of JSC "Uzneftegazdobycha") 
Analysis of the degree of correlation between balance sheet profit and resource taxes showed that its level is quite high - 90\%. These parameters characterize a sufficiently reliable and stable connection (Table 1).

Table 1. Degree of correlation between the balance sheet profit and resource taxes

\begin{tabular}{|l|c|}
\hline Balance sheet profit from resource taxes & 0,903931 \\
\hline Balance sheet profit from subsurface use tax & 0,708138 \\
\hline Balance sheet profit from land tax & 0,631298 \\
\hline Balance sheet profit from property tax & 0,920143 \\
\hline
\end{tabular}

This degree of correlation allows us to determine quite accurately the amount of change in the balance sheet profit depending on changes in resource taxes.

Taking into account a rather high correlation of resource taxes with financial results, one can see their uneven impact on companies. The size of fields under development, the quality of extracted resources, their quantity, development conditions and, finally, the technical equipment and location play a major role here.

The essence of the issue is that the existing taxation system is hopelessly lagging behind and does not provide incentives to increase hydrocarbon production. Across the country, the oil and gas industry is subject to unified tax rates for subsoil use that do not take into account production conditions. As a result, enterprises with hard-to-recover reserves (especially those producing oil) become unprofitable. Given this situation, we propose a differentiation of rates of this tax [1-4].

Differentiation of rates should ensure:

- maximum accounting of mining, geological, economic and geographical characteristics (by the degree of field development), physical and chemical characteristics of produced oil, gas and condensate that affect the level of investment and current costs;

- the maximum technologically possible and economically justified level of oil, gas and condensate extraction;

- stimulation of maintaining and increasing the level of oil, gas and condensate production through the application of new technologies and compliance with technological development schemes;
- stimulation of geological exploration at the expense of own funds of oil and gas producing enterprises;

- encouraging the commissioning of new fields with underdeveloped infrastructure;

- preventing price increases in the domestic market for gas and oil products.

An analysis of the literature used led us to the conclusion that certain positions of the Russian system of differentiation of subsoil use tax rates (mineral extraction tax) are the most acceptable for us.

"The most significant factors affecting oil and gas production costs in Uzbekistan are the following:

- depletion of the field, characterized as the ratio of accumulated production to book reserves, and shows how many reserves have already been recovered;

- the level of watercut in oil and the presence of moisture in gas;

- average daily flow rate of production wells;

- depth of occurrence;

- abnormal pressure and formation pressure;

- Hydrogen saturation of produced gas and sulfur saturation of oil - oil viscosity level".

Taking into account factors affecting hydrocarbon production costs, as well as changes in the situation at the end of 2019, we propose a refined system of correction factors to adjust the prime rate of the subsoil use tax to introduce differentiated taxation of production enterprises (Table 2) [5-8].

Table 2. Draft correction coefficients

\begin{tabular}{|c|c|c|c|c|c|c|c|c|c|c|}
\hline Factors & Value & $\begin{array}{l}\text { Coeff } \\
\text { icient }\end{array}$ & Value & $\begin{array}{l}\text { Coeff } \\
\text { icient }\end{array}$ & Value & $\begin{array}{l}\text { Coeff } \\
\text { icient }\end{array}$ & Value & $\begin{array}{l}\text { Coeff } \\
\text { icient }\end{array}$ & Value & $\begin{array}{l}\text { Coeff } \\
\text { icient }\end{array}$ \\
\hline 1. Development time (years) & $\begin{array}{c}\text { Up to } \\
3 \\
\text { years. }\end{array}$ & 0 & $3-8$ & 0,5 & $8-15$ & 1 & $15-20$ & 0,9 & $\begin{array}{c}\text { Over } \\
20\end{array}$ & 0,5 \\
\hline 2.Developed by (\%) & $\begin{array}{c}\text { Less } \\
\text { than } \\
70\end{array}$ & 1 & $70-80$ & 0,7 & $80-90$ & 0,5 & $90-95$ & 0,2 & $\begin{array}{c}\text { Over } \\
95\end{array}$ & 0 \\
\hline $\begin{array}{l}\text { 3. Average daily flow rate } \\
\text { - oil well (t/ per well) }\end{array}$ & $\begin{array}{c}\text { Over } \\
20\end{array}$ & 1 & $\begin{array}{l}10- \\
20\end{array}$ & 0,7 & $5-10$ & 0,5 & $1-5$ & 0,3 & $\begin{array}{c}\text { Less } \\
\text { than } \\
1\end{array}$ & 0 \\
\hline $\begin{array}{l}\text { - gas condensate well for oil } \\
\text { (thousand } \mathrm{m}^{3} / \text { borehole) }\end{array}$ & $\begin{array}{l}\text { Over } \\
300\end{array}$ & 1 & $\begin{array}{c}300- \\
200\end{array}$ & 0,8 & $\begin{array}{l}100- \\
200\end{array}$ & 0,6 & $\begin{array}{l}10- \\
100\end{array}$ & 0,4 & $\begin{array}{c}\text { Less } \\
\text { than } \\
1\end{array}$ & 0,2 \\
\hline $\begin{array}{l}\text { - gas condensate well by } \\
\text { condensate }(t / \text { per well) }\end{array}$ & $\begin{array}{c}\text { Over } \\
10\end{array}$ & 1 & $\begin{array}{l}5- \\
10\end{array}$ & 0,8 & $\begin{array}{c}2,5- \\
5\end{array}$ & 0,6 & $\begin{array}{l}1- \\
2,5\end{array}$ & 0,4 & $\begin{array}{c}\text { Less } \\
\text { than } \\
1\end{array}$ & 0,2 \\
\hline $\begin{array}{l}\text { 4. Water encroachment level } \\
\text { - oil wells }\end{array}$ & $\begin{array}{l}\text { Up to } \\
50\end{array}$ & 1 & $50-60$ & 0,8 & $60-70$ & 0,6 & $70-80$ & 0,4 & $80-90$ & 0,2 \\
\hline
\end{tabular}




\begin{tabular}{|l|c|c|c|c|c|c|c|c|c|c|}
\hline - gas wells $\left(\mathrm{g} / \mathrm{m}^{2}\right)$ & $\begin{array}{c}\text { Up to } \\
10\end{array}$ & 1 & $\begin{array}{c}\text { Over } \\
10\end{array}$ & 0,6 & & & & & & \\
\hline $\begin{array}{l}\text { 5. Sulfur saturation level } \\
\text { - oil (\%) }\end{array}$ & $\begin{array}{c}\text { Up to } \\
10\end{array}$ & 1 & $2-3$ & 0,75 & $3-9$ & 0,5 & $\begin{array}{c}\text { Over } \\
9\end{array}$ & 0,2 & & \\
\hline - gas (mole \%) & $\begin{array}{c}\text { Up to } \\
1\end{array}$ & 1 & $1-2$ & 0,5 & $\begin{array}{c}\text { Over } \\
2\end{array}$ & 0,3 & & & & \\
\hline - condensate (\%) & $\begin{array}{c}\text { Up to } \\
1\end{array}$ & 1 & $1-2$ & 0,5 & $\begin{array}{c}\text { Over } \\
2\end{array}$ & 0,3 & & & & \\
\hline 6. Oil viscosity level & Easy & 1 & $\begin{array}{c}\text { Parafi } \\
\text { new }\end{array}$ & 0,75 & $\begin{array}{c}\text { Smo- } \\
\text { list }\end{array}$ & 0,5 & & & & \\
\hline 7. Depth of occurrence $(\mathrm{km})$ & $\begin{array}{c}\text { Up to } \\
1\end{array}$ & 1 & $1-2$ & 0,8 & $2-3$ & 0,6 & $3-4$ & 0,45 & $\begin{array}{c}\text { Over } \\
4\end{array}$ & 0,3 \\
\hline
\end{tabular}

For new fields, it is proposed to establish tax exemptions or a zero rate for the first 3 years from the start of production (for the period of development). Throughout the entire development period (except for the initial stage), correction factors are applied to the base tax rate (Table 3 ).

Here is an example of calculating the rate for a conditional field.

Table 3. Conditional calculation of the tax rate for the use of subsoil, adjusted for correction factors

\begin{tabular}{|c|c|c|c|c|c|}
\hline \multirow[b]{2}{*}{ Rate adjustment factors } & \multirow[b]{2}{*}{$\begin{array}{l}\text { Level } \\
\text { factor }\end{array}$} & \multirow[b]{2}{*}{$\begin{array}{l}\text { Base } \\
\text { rate }\end{array}$} & \multicolumn{2}{|c|}{ Adjustments for correction factors } & \multirow[b]{2}{*}{ Final rate } \\
\hline & & & $\begin{array}{l}\text { Correction } \\
\text { size }\end{array}$ & $\begin{array}{l}\text { Calculation of } \\
\text { the adjustment }\end{array}$ & \\
\hline 2. Depth of occurrence $(\mathrm{m})$ & 960 & \multirow{7}{*}{$20 \%$} & 1 & $20 \times 1=20,0$ & \multirow{7}{*}{2,33} \\
\hline 3. Development time (years) & 15 & & 0,9 & $20 \times 0,9=18,0$ & \\
\hline 4. Development (\%) & 80 & & 0,2 & $18,0 \times 0,2=3,6$ & \\
\hline $\begin{array}{l}\text { 5. Average daily flow rate of an oil well }(\mathrm{t} / \\
\text { per well) }\end{array}$ & 70 & & 1 & $3,6 \times 1=3,6$ & \\
\hline 6. Water cut $(\%)$ & 60 & & 0,8 & $3,6 \times 0,8=2,88$ & \\
\hline 7.Saturation level with hydrogen sulfide (\%) & 7 & & 0,9 & $2,88 \times 0,9=2,59$ & \\
\hline ( & $\begin{array}{c}\text { Product of } \\
\text { all } \\
\text { coefficient } \\
\text { values }= \\
0,1166\end{array}$ & & 0,9 & $\begin{array}{c}2,59 \times 0,9= \\
2,33\end{array}$ & \\
\hline & & & & $20 \times 0$ & $166=2,33$ \\
\hline
\end{tabular}

We have made calculations of the impact on the financial condition of enterprises of the proposed method of reducing the specified tax rates for the use of subsoil based on the reporting data for 2019 .

It can be seen from the above table that the application of a differentiated approach even to one tax (tax for the use of subsoil) will make it possible for the Company's mining enterprises as a whole to raise profitability (profit-to-cost ratio) by more than 8 times (from $3.2 \%$ to $27.4 \%$ ) [9-11].

In our opinion, the implementation of the proposed concept of differentiation of the tax rate for the use of mineral resources should be divided into at least 2 stages.

The objectives of the first stage of the transition to differential taxation of hydrocarbon production are:

- creation of a favorable investment climate;

- extending the period of profitable field development, increasing subsurface extraction;

- creation of favorable conditions for the production of hard-to-recover hydrocarbon reserves.

At the first stage, which is about 3 years, it should be, first of all, about stimulating the development of new fields and increasing the production of hydrocarbons.
For this stage, the set of rental factors can be reduced. During this period, most closely reflect the features of the development of deposits, such an indicator as $\%$ depletion.

The level of correction factors is approved annually by order of the Chairman of Uzbekneftegaz JSC in agreement with the Ministry of Economy of the Republic of Uzbekistan and is reported to the tax authorities for execution. The level of reduction factors, based on depletion, is proposed to be approved for each field for the coming year based on the fact for the previous year [12].

The amount of depletion for the fields is determined as the ratio of production accumulated since the commissioning to the initial recoverable reserves put on the balance sheet. For deposits at the final stage of development (over 70\%), decreasing coefficients are applied to the base tax rate for the use of subsoil. At the same time, it is proposed to establish tax holidays for new fields for the period of development for up to 3 years from the start of production.

At the second stage, which is about 5 years, it is proposed to introduce correction factors for the following factors: 
- the depth of occurrence of hydrocarbon reserves in the context of fields;

- average daily debit of 1 well in the field.

Adjustment of tax rates depending on the depth of hydrocarbon deposits can be established for the entire period of the second stage. Adjustment of the rate using a reduction factor based on the average daily debit (production of hydrocarbons by 1 well per day) is made if oil production is below 20 tons per day, 300 thousand $\mathrm{m} 3$ of gas and 10 tons of gas condensate. The zero rate (tax exemption) is applied when one well produces less than 1 ton of oil, 0.2 thousand $\mathrm{m} 3$ of gas or 1 ton of gas condensate per day.

At the third stage, which is also about 5 years old, it is planned to introduce correction factors for deposits based on the following factors:

- oil viscosity level (light, resinous, paraffinic)

- the level of sulfur saturation for oil gas $(\mathrm{mol} \%)$

- the level of saturation with hydrogen sulfide

- percentage of oil water cut $(\%)$.

We also note that the financing of innovative processes and developments is essentially an investment in the modernization and expansion of production. Investments can be both internal and external. It is known that for enterprises, especially enterprises of the fuel and energy complex, internal investments are preferable, since in this situation the enterprise independently decides where to direct them and the profit received as a result of investment remains at the company's full disposal.

Consequently, the application in practice of the mechanism of differentiated taxation proposed by the author will allow enterprises in the extractive industries of the fuel and energy complex to save financial resources, accumulate and further invest them in the development of their innovative activities. It should also be noted that this mechanism is fully consistent with the continuation, at the state level, of the course towards reducing the tax burden and simplifying the taxation system, improving tax administration and expanding measures of appropriate incentives in the form of a system of correction factors to adjust the base tax rate for the use of subsoil to introduce differential taxation of mining enterprises.

\section{References}

1. Decree of the President of the Republic of Uzbekistan No.UP-4947 "On the strategy of actions for the further development of the Republic of Uzbekistan" dated February 7, 2017.

2. Message from the President of the Republic of Uzbekistan Shavkat Mirziyoyev to the Oliy Majlis of the Republic of Uzbekistan dated December 23, 2017.

3. Allaev K.R. Energy of the world and Uzbekistan. T. "Molia", 388 p.

4. Allaeva G.Zh. Innovative potential of the fuel and energy complex of the Republic of Uzbekistan. //Monograph. - Toshkent, "Fan va texnologiyalar" nashriyoty, 2017. - bet 160 .
5. Ivonina I.E. Management of sustainable development of enterprises in the oil and gas industry. - Tashkent, 2013, - 202 p. 161.

6. Allaeva G.Zh. "Effective development of activities of enterprises of the fuel and energy complex." 08.00.03. Industrial economics. Dissertation for the degree of Doctor of Philosophy (PhD) in Economics. Tashkent 2018.

7. "Tax for the use of subsoil: problems and ways of improvement." Ivonina I.E. Draft analytical report on improving taxation of subsoil users. Tashkent 2016.

8.Hoshimov, F.A., Bakhadirov, I.I., Erejepov, M., Djumamuratov, B. (2019) Development of method for normalizing electricity consumption E3S Web Conf 139 doi:10.1051/e3sconf/201913901074

9.Allayev, K.R., Fedorenko, G.M.,Postnikov, V.I.,Ostapchuk, L.B. Asynchronous generators as power system's natural dampers. 43rd International Conference on Large High Voltage Electric Systems 2010, CIGRE 20102010, 9p43rd International Conference on Large High Voltage Electric Systems 2010, CIGRE 2010; Paris; France; 22 August 2010.

10. Fazylov, Kh.F.,Allaev, K.R. Analysis of the operation of an electrical system during simultaneous operation of synchronous and asynchronous generators. Power engineering New York Volume 18, Issue 3, 1980, Pages 81-88.

11.Fazylov, Kh.F.,Allaev, K.R. Asynchronous turbogenerators with stator excitation and the prospects for their utilization. Power engineering New York Volume 23, Issue 2, 1985, Pages 7-13.

12.Fazylov, Kh.F.,Allaev, K.R. Calculation and experimental analysis of conditions of electrical power systems containing induction generators Power Engineering New York Volume 27, Issue 6, 1989, Pages 27-34. 